Article

\title{
Synthesis and Characterization of Some New Tetraaldehyde and Tetraketone Derivatives and X-ray Structure of 1,1'-(4,4'-(2- (1,3-bis(4-Acetylphenoxy)propan-2-ylidene)propane-1,3-di- yl)bis(oxy)bis(4,1-phenylene))diethanone
}

\author{
Mustafa Er ${ }^{1}$, Reşat Ustabaş ${ }^{2, *}$, Ufuk Çoruh ${ }^{3}$, Kemal Sancak ${ }^{1}$ and Ezequiel Vázquez-López ${ }^{4}$ \\ 1 Department of Chemistry Faculty of Arts and Sciences Karadeniz Teknik University, 61080- \\ Trabzon, Turkey; E-mails: muser@ktu.edu.tr; ksancak@ktu.edu.tr \\ 2 Department of Middle Education, Educational Faculty, Ondokuz Mayıs University 55200-Atakum- \\ Samsun, Turkey \\ 3 Department of Computer Education and Instructional Technology, Educational Faculty, Ondokuz \\ Mayıs University 55200-Atakum-Samsun, Turkey; E-mail: ucoruh@omu.edu.tr \\ 4 Departamento de Química Inorgánica, Facultade de Ciencias-Química, Universidade de Vigo, \\ 36200-Vigo, Galicia, Spain; E-mail: ezequiel@uvigo.es
}

* Author to whom correspondence should be addressed. E-mail: rustabas@omu.edu.tr

Received: 26 November 2007; in revised form: 15 April 2008 / Accepted: 18 April 2008 /

Published: 13 June 2008

\begin{abstract}
Tetraketone and tetraaldehyde derivatives 2a-d were synthesized via the reaction of ethene-1,1,2,2,-tetra-yl-tetramethylene tetrabromide (1) with hydroxyketone and aldehyde derivatives. The molecular structures were identifed by $\mathrm{IR},{ }^{1} \mathrm{H}-\mathrm{NMR},{ }^{13} \mathrm{C}-$ NMR and MS analysis. The crystal structure of the title compound $\mathbf{2 a}, \mathrm{C}_{38} \mathrm{H}_{36} \mathrm{O}_{8}$, is reported. Its crystal data are: monoclinic, space group $\mathrm{P} 2(1) / \mathrm{n}$ with cell dimensions of $\mathrm{a}=$ 9.0395(12) $\AA, b=12.6114(17) \AA, c=13.8166(18) \AA, \beta=95.875(3), V=1566.8(4) \AA^{3}$, $\mathrm{F} . \mathrm{W} .=620.67, \rho_{\text {calc }}=1.316 \mathrm{gcm}^{3}$ for $\mathrm{Z}=2, \mu=0.092 \mathrm{~mm}^{-1}$
\end{abstract}

Keywords: 1,3-bis(4-Acetylphenoxy)propan-2-ylidenepropane; 1,3-di-ylbis(oxy)bis(4,1phenylene))diethanone; crystal structure; $x$-ray 


\section{Introduction}

Acetophenone (AP, phenylmethylketone or hypnone) is used in consumer fragrances and as an industrial solvent [1]. Acetophenone and its derivatives are important compounds for obtaining biologically active compounds. In general, acetophenones are an important constituent of effective therapeutics against mycobacteria [2]. Acetophenones are used to obtain benzofuran, and its ketoxime derivatives show antifungal activities [3]. In adddition, acetophenones which contain halogens are used to synthesize disubstituted 1,3-thiazole compounds that have selective human adenosine A3 receptor antagonist [4] as well as antifungal and antibacterial activities. Some acetophenone derivatives have antimicrobial activity against gram-positive bacteria and fungi [5] while others are used as herbicides [6]. Certain acetophenones carrying a hydroxyl group at C-2 have antimutagenic activity in Salmonella typhimurium [7]. Many acetophenones are found as natural products in plants [8] and fungi [9]. The oral administration of Paeonol (2-hydroxy-4-methoxy acetophenone) to rats is followed by rapid excretition in the urine as its sulphated derivative [10]. Some acetophenone semicarbazone and acetophenone oxime derivatives are used to obtain biologically active industrial polimers [11]. $O$ Hydroxyacetophenone oxime is an important analytical reagent for the gravimetric and colorimetric estimation of transition metals [12]. Acetophenone derivatives are very interesting model compounds as foreign substrates for biotransformation, because an enantiomer may be formed, which can be determined easily. These compounds have been effectively used as a building blocks for the asymmetric synthesis of drugs [13].

In a part of our study, we aimed to enhance the selectivity of these macromolecular compounds and the stability of the Schiff base formed with both various amines and heterocyclic moiety. So, we prepared macromolecular compounds having aldehyde and ketone functions connection by flexible bridge. In this study, tetraaldehyde and tetraketone derivatives $\mathbf{2 a - d}$ were obtained from the reaction with ethene-1,1,2,2-tetra-yl-tetra methylene tetra bromide (1) with hydroxyaldehydes and hydroxyketones.

\section{Experimental}

\subsection{Materials}

Melting points were determined on a Gallenkamp melting point apparatus and are uncorrected. ${ }^{1} \mathrm{H}-\mathrm{NMR}$ and ${ }^{13} \mathrm{C}$-NMR spectra were recorded on a Varian-Mercury $200 \mathrm{MHz}$ spectrometer. The IR spectra were measured as potassium bromide pellets using a Perkin-Elmer 1600 series FTIR spectrometer. The MS spectra were determined on a Micromass Quatro LC/ULTIMA LC-MS spectrometer. Elemental analyses was carried out on a $\mathrm{C}, \mathrm{H}, \mathrm{N}-\mathrm{O}$ rapid elemental analyzer HewlettPackard 185 for $\mathrm{C}, \mathrm{H}$ and $\mathrm{N}$ and results are with in $0.4 \%$ of the theoretical values. All the chemicals were obtained from Fluka Chemie AG Buchs (Switzerland). Compound 1 was synthesized using the published methods [14]. 
2.2. Synthesis of 1,1'-(4,4'-(2-(1,3-bis(4-acetylphenoxy)propan-2-ylidene)propane-1,3-di-yl)bis(oxy)bis (4,1-phenylene)) diethanone (2a)

4-Hydroxyacetophenone $(0.04 \mathrm{~mol})$ and potassium hydroxide $(0.04 \mathrm{~mol})$ were refluxed in absolute ethanol for 2 hours. 1,1,2,2-Tetra-yl-tetramethylene tetrabromide (0.01) was added to the reaction mixture which was refluxed for 20 hours. The mixture was filtered and the solvent was evaporated. The solid residue was recrystallized from chloroform-acetone (1:1) to give compound 2a (yield $73 \%$; m.p. 440-441 ${ }^{\circ} \mathrm{K}$ ). Analysis (\% Calculated/found) for $\mathrm{C}_{38} \mathrm{H}_{36} \mathrm{O}_{8}(\mathrm{Mw}$ 620.7) C: 73.53/73.44, $\mathrm{H}$ : 5.85/5.82; IR (KBr) $\left(v, \mathrm{~cm}^{-1}\right), 3045(\mathrm{Ar}-\mathrm{CH}), 2938(-\mathrm{CH}), 1674(\mathrm{C}=\mathrm{O}) ;{ }^{1} \mathrm{H}-\mathrm{NMR}\left(\mathrm{DMSO}-\mathrm{d}_{6}\right) \delta(\mathrm{ppm})$ $2.51\left(\mathrm{~s}, 12 \mathrm{H}, \mathrm{CH}_{3}\right), 4.99\left(\mathrm{~s}, 8 \mathrm{H}, \mathrm{O}-\mathrm{CH}_{2}\right), 7.04-7.92\left(\mathrm{dd}, 16 \mathrm{H}, \mathrm{J}=8.0 \mathrm{~Hz}, \mathrm{AA}^{\prime} \mathrm{XX}\right.$, Ar-H); ${ }^{13} \mathrm{C}-\mathrm{NMR}$ $\left(\mathrm{DMSO}_{6}\right) \delta(\mathrm{ppm}) 26.35\left(\mathrm{CH}_{3}\right), 64.90\left(\mathrm{O}-\mathrm{CH}_{2}\right), \operatorname{Ar}-\mathrm{C}$ : [114.50 $(\mathrm{CH}), 130.07(\mathrm{C}), 100.29(\mathrm{CH})$, $161.99(\mathrm{C})], 135.05(\mathrm{C}=\mathrm{C}), 196.24(\mathrm{C}=\mathrm{O})$; MS: m/z $621.34(\mathrm{M}+1)^{+1}$.

\subsection{Synthesis of (4,4'-(2-(1,3-bis(4-benzoylphenoxy)propan-2-ylidene)propane-1,3-diyl)bis(oxy)bis} (4,1-phenylene))bis(phenylmethanone) (2b)

4-Hydroxybenzophenone $(0.04 \mathrm{~mol})$ and potassium hydroxide $(0.04 \mathrm{~mol})$ refluxed in absolute ethanol for 2 hours. 1,1,2,2-Tetra-yl-tetramethylene tetrabromide $(0.01)$ was added to the reaction mixture, which was then refluxed for 20 hours. The mixture was filtered and the solvent was evaporated. The solid residue was recrystallized from DMF-ethyl alcohol (2:1) to give compound $\mathbf{2 b}$ (yield $64 \%$; m.p. 467-468 K). Analysis (\% Calculated/found) for $\mathrm{C}_{58} \mathrm{H}_{44} \mathrm{O}_{8}$ (Mw 869.0) C: 80.17/80.26, H: 5.10/5.14; IR (KBr) ( $\left.v, \mathrm{~cm}^{-1}\right), 3065$ (Ar-CH), $2970(-\mathrm{CH}), 1652$ (C=O); ${ }^{1} \mathrm{H}-\mathrm{NMR}$ $\left(\mathrm{DMSO}_{6}\right) \delta(\mathrm{ppm}) 5.07\left(\mathrm{~s}, 8 \mathrm{H}, \mathrm{O}-\mathrm{CH}_{2}\right), 7.13-7.57\left(\mathrm{dd}, 16 \mathrm{H}, \mathrm{J}=8.2 \mathrm{~Hz}, \mathrm{AA}^{\prime} \mathrm{XX}^{\prime}, \mathrm{Ar}-\mathrm{H}\right), 7.62-7.65$ $(\mathrm{m}, 8 \mathrm{H}, \mathrm{Ar}-\mathrm{H}), 7.69-7.71(\mathrm{~m}, 8 \mathrm{H}, \mathrm{Ar}-\mathrm{H}), 7.75$ (m, 4H, Ar-H); ${ }^{13} \mathrm{C}-\mathrm{NMR}\left(\mathrm{DMSO}_{\mathrm{d}}\right) \delta$ (ppm) 64.96 $\left(\mathrm{O}-\mathrm{CH}_{2}\right)$, Ar-C: [114.57 (CH), $128.34(\mathrm{CH}), 129.17(\mathrm{CH}), 129.58(\mathrm{C}), 131.98(\mathrm{CH}), 132.06(\mathrm{CH})$, $137.55(\mathrm{C}), 161.87(\mathrm{C})], 135.12(\mathrm{C}=\mathrm{C}), 194.30(\mathrm{C}=\mathrm{O})$; MS: m/z $869.31(\mathrm{M}+1)^{+1}$.

2.4. Synthesis of 2,2'-(2-(1,3-bis(2,4-dichloro-6-formylphenoxy)propan-2-ylidene)propane-1,3-diyl)bis (oxy)bis(3,5-dichlorobenzaldehyde) (2c)

3,5-Dichlorosalicylaldehyde $(0.04 \mathrm{~mol})$ and potassium hydroxide $(0.04 \mathrm{~mol})$ were refluxed in absolute ethanol for 2 hours. 1,1,2,2-Tetra-yl-tetramethylene tetrabromide (0.01) was added to the reaction mixture, which was refluxed for 20 hours. The mixture was filtered and the solvent was evoporated. The solid residue was recrystallized from ethyl alcohol to give compound 2c (yield $63 \%$; m.p. 478-479 $\mathrm{K}$ ). Analysis (\% Calculated/found) for $\mathrm{C}_{34} \mathrm{H}_{20} \mathrm{Cl}_{8} \mathrm{O}_{8}(\mathrm{Mw} 840.1) \mathrm{C}: 48.61 / 48.53$, $\mathrm{H}$ : 2.40/2.38; IR (KBr) (v, cm $\left.{ }^{-1}\right), 3067$ (Ar-CH), $2972(-\mathrm{CH}), 2883-2894(\mathrm{CHO}), 1696(\mathrm{C}=\mathrm{O}) ;{ }^{1} \mathrm{H}-\mathrm{NMR}$ $\left(\mathrm{DMSO}_{6}\right) \delta(\mathrm{ppm}) 5.07$ (s, 8H, O-CH 2$), 7.63-7.64(\mathrm{~d}, 4 \mathrm{H}, \mathrm{Ar}-\mathrm{H}), 7.98-7.99(\mathrm{~d}, 4 \mathrm{H}, \mathrm{Ar}-\mathrm{H}), 10.05$ (s, $4 \mathrm{H},-\mathrm{CHO}) ;{ }^{13} \mathrm{C}-\mathrm{NMR}\left(\mathrm{DMSO}-\mathrm{d}_{6}\right) \delta(\mathrm{ppm}) 55.99\left(\mathrm{O}_{-} \mathrm{CH}_{2}\right), \mathrm{Ar}-\mathrm{C}:[127.3157(\mathrm{C}), 128.67(\mathrm{C}), 129.61$ (C), $131.05(\mathrm{CH}), 135.21(\mathrm{CH}), 154.92(\mathrm{C})], 135.05(\mathrm{C}=\mathrm{C}), 188.17(\mathrm{C}=\mathrm{O}) ; \mathrm{MS}: \mathrm{m} / \mathrm{z} 882.50$ $\left(\mathrm{M}+\mathrm{Na}+\mathrm{H}_{2} \mathrm{O}\right)^{+1}$. 
2.5. Synthesis of 2,2'-(2-(1,3-bis(2-bromo-4-chloro-6-formylphenoxy)propan-2-ylidene)propane-1,3diyl)bis (oxy)bis(3-chloro-5-bromo benzaldehyde) (2d)

3-Chloro-5-bromosalicylaldehyde $(0.04 \mathrm{~mol})$ and potassium hydroxide $(0.04 \mathrm{~mol})$ were refluxed in absolute ethanol for 2 hours. 1,1,2,2-Tetra-yl-tetramethylene tetrabromide (0.01) was added to the reaction mixture, which was refluxed for 20 hours. The mixture was filtered and the solvent was evaporated. The solid residue was recrystallized from DMF-ethyl alcohol (1:1) to give compound 2d (yield $54 \%$; m.p. 485-486 ${ }^{\circ} \mathrm{K}$ ). Analysis (\% Calculated/found) for $\mathrm{C}_{34} \mathrm{H}_{20} \mathrm{Br}_{4} \mathrm{Cl}_{4} \mathrm{O}_{8}$ (Mw 1017.9) C: 40.12/40.17, H: 1.98/2.01; IR (KBr) (v, cm $\left.{ }^{-1}\right), 3075$ (Ar-CH), 2977 (-CH), 2796-2884 (CHO), 1698 $(\mathrm{C}=\mathrm{O}) ;{ }^{1} \mathrm{H}-\mathrm{NMR}\left(\mathrm{DMSO}_{6}\right) \delta(\mathrm{ppm}) 5.01\left(\mathrm{~s}, 8 \mathrm{H}, \mathrm{O}-\mathrm{CH}_{2}\right), 7.44$ (s, 4H, Ar-H), $7.83(\mathrm{~s}, 4 \mathrm{H}, \mathrm{Ar}-\mathrm{H})$, $10.18(\mathrm{~s}, 4 \mathrm{H},-\mathrm{CHO}) ;{ }^{13} \mathrm{C}-\mathrm{NMR}\left(\mathrm{DMSO}_{\mathrm{d}}\right) \delta(\mathrm{ppm}) 55.93\left(\mathrm{O}-\mathrm{CH}_{2}\right), \operatorname{Ar}-\mathrm{C}:[117.93(\mathrm{C}), 126.82(\mathrm{C})$, $129.06(\mathrm{C}), 132.67(\mathrm{CH}), 135.63(\mathrm{CH}), 152.12(\mathrm{C})], 135.45(\mathrm{C}=\mathrm{C}), 188.26(\mathrm{C}=\mathrm{O})$.

\subsection{Crystallographic structure determination compound 2a}

A summary of the key crystallographic information is given in Table 1. The data was collected on a smart [15] CCD diffractomer using graphite-monochromated Mo K $\alpha$ radiation at room temperature. The collected data were reduced by using the program SAINT [15] and empirical absorption correction was carried out by using the SADABS [16] program. The structure was solved by direct methods [17] as implemented in the SHELXTL system of computer programmes and refined to convergence by full matrix least-squares methods. $\mathrm{H}$ atoms were located geometrically and then refined isotropically with fixed displacement parameters. Atomic scattering factors used were those from the International Table for x-ray crystallography [18]. The crystal structure has been deposited at the Cambridge Crystallographic Data Center with the deposition number CCDC 686161.

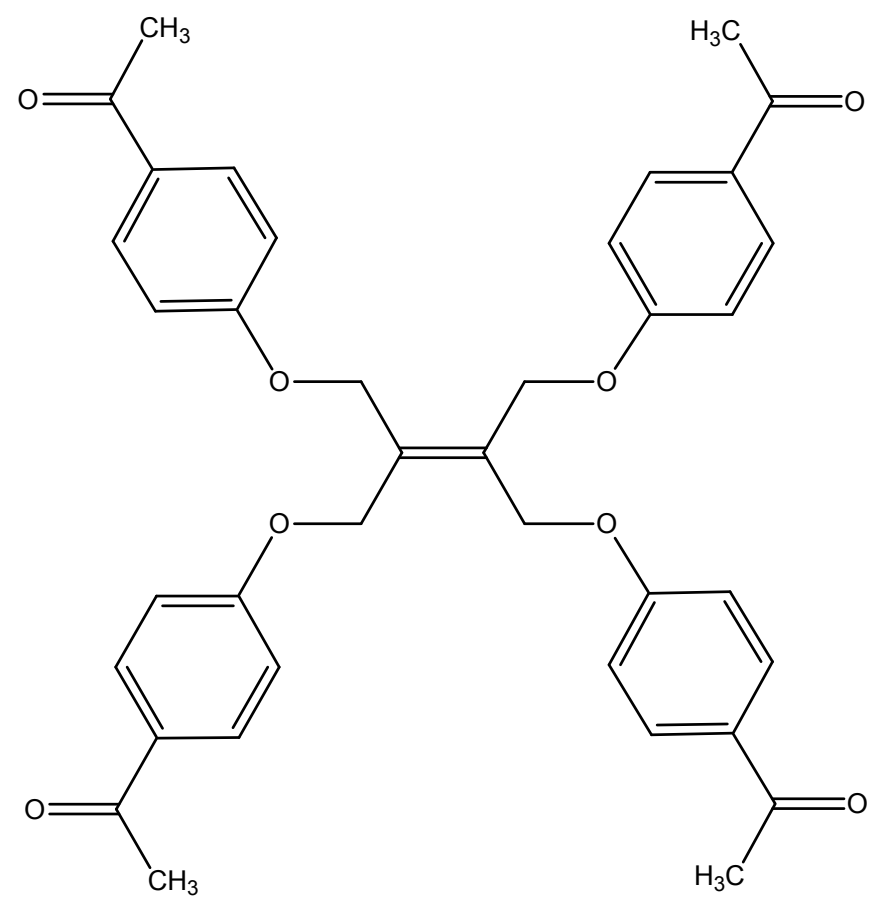


Table 1. Crystallographic data for $\mathrm{C}_{38} \mathrm{H}_{36} \mathrm{O}_{8}$

\begin{tabular}{|c|c|c|c|}
\hline $\begin{array}{l}\text { Chemical formula } \\
\text { Formula weight }\end{array}$ & $\begin{array}{c}\mathrm{C}_{38} \mathrm{H}_{36} \mathrm{O}_{8} \\
620.67\end{array}$ & $\begin{array}{l}\alpha\left(^{\circ}\right) \\
\left.\beta r^{\circ}\right)\end{array}$ & $\begin{array}{c}90 \\
95.875(3)\end{array}$ \\
\hline Crystal colour, habit & Colourless, prism & $\gamma\left(0^{\circ}\right)$ & 90 \\
\hline Crystal system & Monoclinic & $\mathrm{V}\left(\AA^{3}\right)$ & $1566.8(4)$ \\
\hline Crystal dimensions & $0.30 \times 021 \times 0.21$ & $\mathrm{Z}$ & 2 \\
\hline Space group & P $21 / n$ & $D_{\text {calc }}\left(g / \mathrm{cm}^{3}\right)$ & 1.316 \\
\hline $\mathrm{a}(\AA)$ & $9.0395(12)$ & $\mu($ Mo K $\alpha), \mathrm{cm}^{-1}$ & 0.092 \\
\hline $\mathrm{b}(\AA)$ & $12.6114(17) 13.8166(18)$ & No unique reflections & 8396 \\
\hline$c(\AA)$ & & No of observations & 2430 \\
\hline & & $\mathrm{R}$ & 0.0481 \\
\hline & & $\mathrm{R}_{\mathrm{w}}$ & 0.0722 \\
\hline
\end{tabular}

Table 2. Selected geometric parameters $\left(\AA,^{\circ}\right)$ for $\left[\mathrm{C}_{38} \mathrm{H}_{36} \mathrm{O}_{8}\right]$

C10-C10' 1.332(6) C15-C17-C16 118.7(3)

O1-C2 1.218(3) C15-C17-C18 123.7(3)

O4-C18 1.226(3) C16-C17-C18 117.5(3)

C4-C3-C5 118.0(3) C8-O2-C9-C10 159.8(2)

C4-C3-C2 119.9(3) C12-O3-C11-C10 -173.0(2)

C5-C3-C2 122.0(3)

Figure 1. ORTEP drawing of the crystal structure of $\mathrm{C}_{38} \mathrm{H}_{36} \mathrm{O}_{8}$

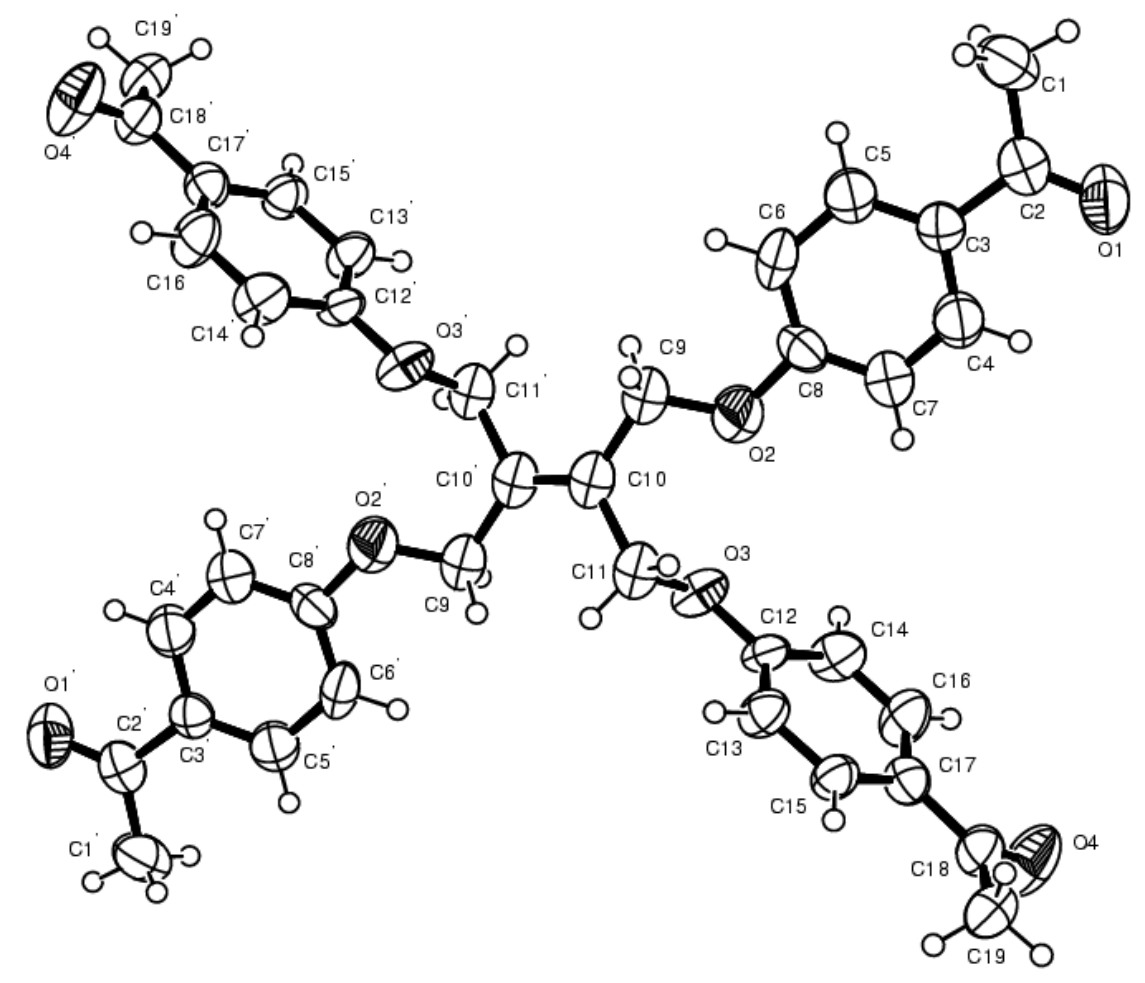




\section{Results and Discussion}

The reaction of ethene-1,1,2,2-tetra-yl-tetramethylene tetra- bromide (1) in absolute ethanol media with the corresponding potassium salts of phenolic ketones and aldehydes (obtained by potassium hydroxide solution) gave the corresponding tetraketones $\mathbf{2 a , b}$ or tetraaldehydes $\mathbf{2 c}, \mathbf{d}$ in a good yield (Scheme 1). The substitution reactions were highly selective for the tetrasubstituted products $\mathbf{2}$, as independent of the molar ratios of ketophenol or aldehydophenol. Mono-, di- or trisubstituted products could not be obtained in this reaction. In the IR spectra of compounds 2a-d, one sharp absorption band was seen at 1652-1698 $\mathrm{cm}^{-1}$ which is assigned to the carbonyl functions. The CHO Fermi doublet stretching frequency was observed at $2796-2894 \mathrm{~cm}^{-1}$ in the IR spectra of compounds $\mathbf{2 c , d}$.

Scheme 1. Synthesis and structures of compounds 2a-d

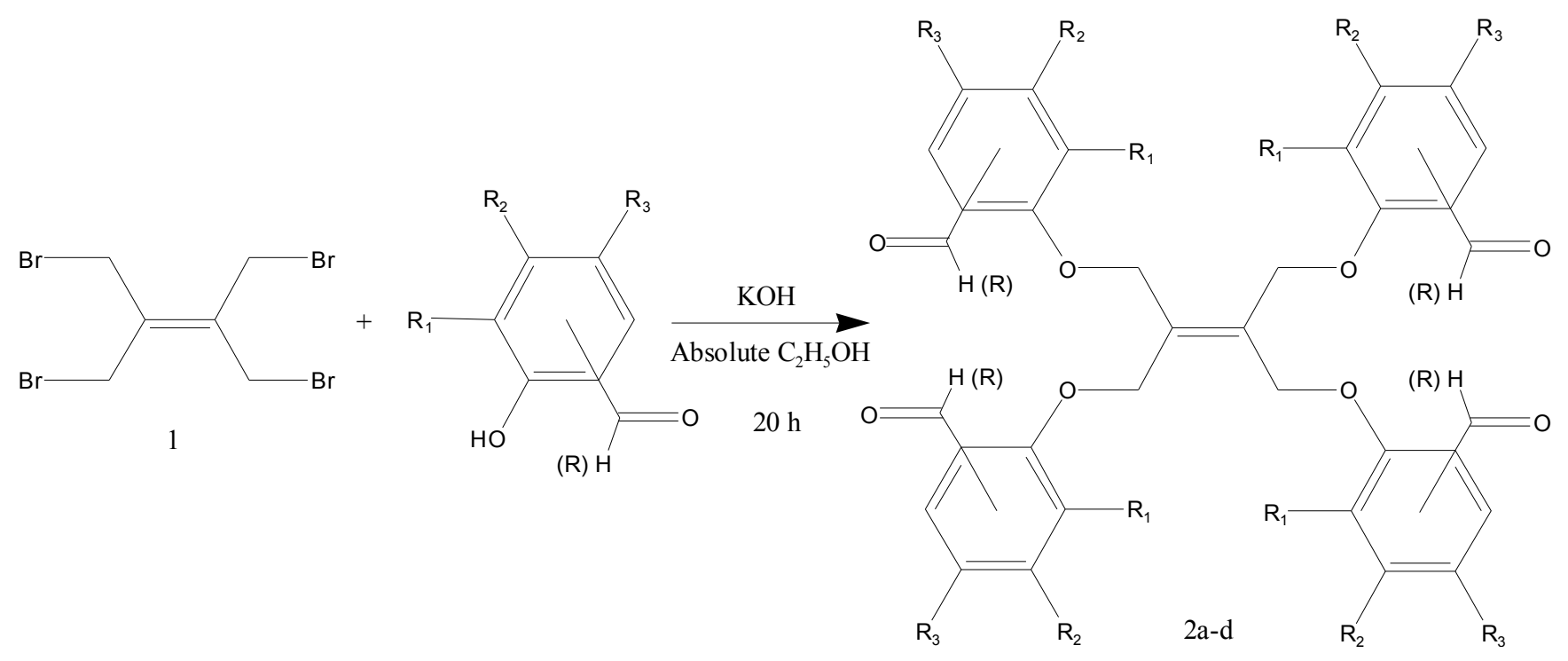

a
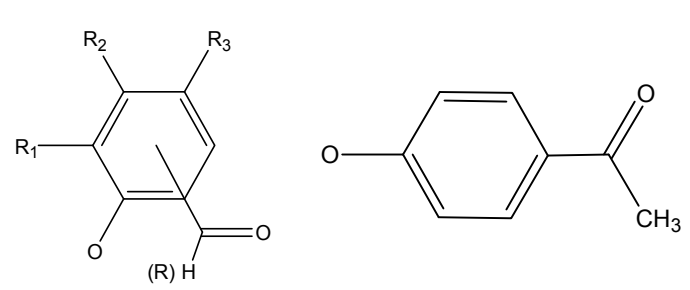

b

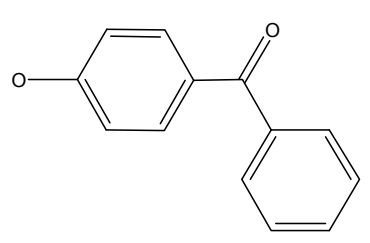

c

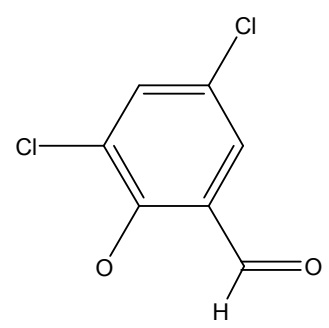

d

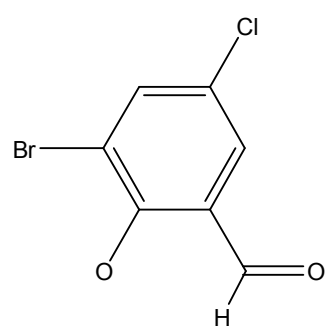

In the ${ }^{1} \mathrm{H}-\mathrm{NMR}$ spectra of compounds $\mathbf{2 a - d}$ the signals of the $\left(-\mathrm{O}-\mathrm{CH}_{2}\right)$ methylene groups integrating for eight protons were seen between 4.99-5.07 ppm. Aldehyde protons (CHO) of compounds 2 c, $\mathbf{d}$ were observed around $10.05-10.18 \mathrm{ppm}$, integrating for four protons. In the ${ }^{13} \mathrm{C}-\mathrm{NMR}$ of compounds $2 \mathrm{a}-\mathrm{d}, \mathrm{OCH}_{2}$ group was observed at $56-65 \mathrm{ppm}$. In addition, $\mathrm{C}=\mathrm{O}$ and $\mathrm{C}=\mathrm{C}$ functions of compounds 2a-d appeared at 188-196 ppm and 134-135 ppm, respectively. ${ }^{1} \mathrm{H}-\mathrm{NMR}$ and ${ }^{13} \mathrm{C}-\mathrm{NMR}$ spectral data of compounds 2 a-d are presented in the Experimental section in this study.

The molecule of the title compound 2a has a centre of symmetry located at the mid-point of the $\mathrm{C}=\mathrm{C}$ double bond. The centre of symmetry $\mathrm{C}=\mathrm{C}$ bond length [1.332(6) $\AA$ ] agrees with the values 
reported in the literature [1.335(5) $\AA$ in $\mathrm{C}_{50} \mathrm{H}_{36} \mathrm{O}_{8}$ [19], 1.316(7) $\AA$ in $\mathrm{C}_{12} \mathrm{H}_{12} \mathrm{~N}_{4} \mathrm{~S}_{2}$ [20] and 1.318(6) $\AA$ in $\mathrm{C}_{12} \mathrm{H}_{18} \mathrm{~N}_{2} \mathrm{~S}_{4}$ [21]]. The molecular conformation is essentially described by torsion angles about the C10-C9 and $\mathrm{C} 10-\mathrm{C} 11$ bonds. The $\mathrm{C} 10-\mathrm{C} 11-\mathrm{O} 3-\mathrm{C} 12$ and $\mathrm{C} 10-\mathrm{C} 9-\mathrm{O} 2-\mathrm{C} 8$ torsion angles are $-173.0(2)^{\circ}$ and $159.8(2)^{\circ}$, respectively. The acetyl group is almost complanar with the benzene ring [C15-C17$\left.\mathrm{C} 18=\mathrm{O} 4=179.1(3)^{0}\right]$. The $\mathrm{O}-\mathrm{C}$ bond lengths are within normal ranges. Atoms $\mathrm{C} 3$ and $\mathrm{C} 17$, carrying the acetyl substituents, are trigonal, the sum of the three bond angles around them being $359.9(3)^{\circ}$. As expected, the benzene rings systems are planar, with the largest deviations being 0.0159(3) $\AA$ for C8 and 0.0132(1) $\AA$ for $\mathrm{C} 15$. The dihedral angle between the planes of rings are $76.43(8)^{\circ}$. Atom H9A of the methylene group (C9) forms an intermolecular hydrogen bond with the acetyl group $\mathrm{O}$ atom (O4) of a symmetry-related molecule $\left[\mathrm{C} 9 . . . \mathrm{O} 4^{(\mathrm{i})}=3.159 \AA\right.$; symmetry code: (i) $\left.\mathrm{x}-1,+\mathrm{y},+\mathrm{z}\right]$.

\section{Conclusions}

In order to investigate the influence of the flexibility of the ligand molecule, four new carbonyl compounds have been synthesized and the crystal structure of compound 2a was determined. Alkenetetrayltetra oxyphenylaldehyde and tetraketones were obtained by reaction four different hydroxyketones or hydroxyaldehydes and ethene-1,1,2,2-tetra-yl-tetramethylene tetra- bromide (1). So, we successfully prepared $\mathrm{C}=\mathrm{O}$ functionalized chelates having ether bridges as a key intermediate for the synthesis of novel macromolecules containing a donor group. The compounds were prepared and identified by elemental analysis, IR, ${ }^{1} \mathrm{H}-\mathrm{NMR},{ }^{13} \mathrm{C}-\mathrm{NMR}$ and Mass spectroscopy. In addition, the crystal structure of the compound $\mathbf{2 a}, \mathrm{C}_{38} \mathrm{H}_{36} \mathrm{O}_{8}$, was determined by single crystal X-ray diffraction technique, figure 1.

\section{Acknowledgements}

This work was supported by the Research Fund of Karadeniz Technical University (Project No: 2006.111.025)

\section{References and Notes}

1. Singh, B. K.; Jetley, U. K.; Sharma, R. K. and Garg, B. S. Synthesis, characterization and biological activity of complexes of 2-hydroxy-3,5-dimethylacetophenoneoxime (HDMAOX) with copper(II), cobalt(II), nickel(II) and palladium(II). Spectrochimica Acta Part A 2007, 68, 63-73.

2. Rajabi, L.; Courreges, C.; Montoya, J.; Aguilera, R. J. and Primm, T. P. Acetophenones with selective antimycobacterial activity. Lett. Appl. Microbiol. 2005, 40, 212.

3. Gündoğdu-Karaburun, N.; Benkli, K.; Tunalı, Y.; Uçucu, Ü.; Demirayak, Ş. Synthesis and antifungal activities of some aryl [3-(imidazol-1-yl/triazol-1-ylmethyl)benzofuran-2-yl] ketoximes. Eur. J. Med. Chem. 2006, 41, 651-656.

4. Jung, K. Y.; Kim, S.K.; Gao, Z.G.; Gross, A.S.; Melman, N.; Jacobson, K.A. and Kim, Y.C.; Structure-activity relationships of thiazole and thiadiazole derivatives as potent and selective human adenosine A[3] receptor antagonists. Bioorg. Med. Chem. 2004, 12, 613-623.

5. Gul, H. I.; Denizci, A. A. and Erciyas, E.Antimicrobial evaluation of some Mannish bases of acetophenones and representative quaternary derivatives. Arzneimittel Forschung. 2002, 52, 773. 
6. Teruyuki, M.; Yoshiharu, H. and Ka, Y. Oxime derivative thereof, Process for preparing thereof, Herbicidal composition and methods for the destruction of undesirable weeds, Asahi Chemical Ind., Japan, 1986.

7. Miyazawa, M.; Shimamura, H. and Nakamura, S. Suppression of furylfuramide-induced SOS response by acetophenones using Salmonella typhimurium TA1535/pSK1002 umu test. J. Agric. Food Chem. 2000, 48, 4377.

8. Guyot, C.; Bouseta, A. and Scheirman,V.V. Floral origin markers of chestnut and lime tree honeys, J. Agric. Food Chem. 1998, 46, 625.

9. Wilkins, C. K. and Scholl, S. Volatile metabolites of some barley storage molds Int. J. Food Microbiol. 1989, 8, 11.

10. Yasuda, T.; Kon, R.; Nakazawa, T. and Ohsawa, K. Metabolism of Paeonol in Rats J. Nat. Product 1999, 62, 1142.

11. Soykan, C. and Erol, İ. Synthesis, Characterization, and Biologicaj Activity of N-(4-Acetylphenyl) maleimide and Its Oxime, Carbazone, Thiosemicarbazone Derivatives and Their Polymers. J.Polymer Science, Polymer Chem. 2003, 41, 1942-1951.

12. Poddar, S. N. Ortho-hydroxy acetophenone oxime as an analytical reagent. Part I Analyt. Bioanalyt. Chem. 1957, 154, 254.

13. Yadav, J. S.; Reddy, P. T.; Nanda, S. and Rao, A. B. Stereoselective synthesis of $(R)-(-)-$ denopamine, $(R)-(-)$-tembamide and $(\mathrm{R})-(-)$-aegeline via asymmetric reduction of azidoketones by Daucus carota in aqueous medium . Tetrahedron:Asymmetry 2001, 12, 3381-3385.

14. Cope, A.C. and Kagan, F. Cyclic Polyolefins. J. Am. Chem. Soc. 1958, 80, 5499-5502.

15. Siemens: SMART and SAINT. Area Detector Control and Integration Software; Siemens Analytical X-ray Systems Inc., Madison, Wisconsin, USA, 1996.

16. Sheldrick, G.M. SADABS. Program for Empirical Absorption Correction of Area Detector Data,University of Göttingen, Germany, 1996.

17. Karle, J.; Karle, I.; The symbolic addition procedure for phase determination for centrosymmetric and non-centrosymmetric crystals. Acta Crystallogr. 1996, 21, 849-859

18. International Tables for X-ray Crystallography; Kynoch: Birmingham, UK, 1974; Vol. IV (present distributor: Reidel: Dordrecht, Netherlands).

19. Ustabaş, R.; Çoruh, U.; Er, M.; Serbest, K. and Vazquez-Lopez, E.M. 2,2'-[2,3-Bis(1-formyl-2naphthyloxymethyl)but-2-ene-1,4-diyldioxy]bis(naphthalene-1-carbaldehyde. Acta Cryst. 2006, E62, o5006-05007.

20. Zhang, H.Y.; Sun, H.; Mu, S.C.; Wang, J.K. and Chen, W. trans-1,4-Bis(pyrimidin-2ylsulfanyl)but-2-ene. Acta Cryst. 2005, E61, o4142-04143.

21. Wang, J.; Wang, W.; Chi, H.J. and Yang, Q.S. trans-2,2'-[(2-Butene-1,4-diyl)dithio]bis(4,5dihydro-1,3-thiazine). Acta Cryst. 2006, E62, o4621-o4622.

(C) 2008 by the authors; licensee Molecular Diversity Preservation International, Basel, Switzerland. This article is an open-access article distributed under the terms and conditions of the Creative Commons Attribution license (http://creativecommons.org/licenses/by/3.0/). 